\title{
Similarities of Guamanian ALS/PD to Post-Encephalitic Parkinsonism/ALS: Possible Viral Cause
}

\author{
Arthur J. Hudson and George P.A. Rice
}

\begin{abstract}
Guamanian amyotrophic lateral sclerosis with parkinsonism-dementia (ALS/PD) has been the subject of intensive study since its discovery in 1947 because of its extraordinarily high incidence in a small ethnic group (Chamorros) whose dietary lack and customs have suggested possible causes. As yet, these and other suspected causes have eluded proof. Because of marked similarities between Guamanian ALS/PD and late onset post-encephalitic (encephalitis lethargica) parkinsonism and ALS it is suggested that they have a common cause. The parkinsonism and ALS in the two disorders are clinically very similar and neuropathological studies have shown a very similar distribution of neurofibrillary tangles in neurons. Some clinical differences, such as ocular features in the post-encephalitic cases and dementia in Guamanian ALS/PD, can be explained by differences in the severity of infection and the interval between the encephalitis and onset of sequelae. Although unproven, influenza A (HswilNl strain) has long been suspected as the cause of encephalitis lethargica because of simultaneous pandemics of the two diseases in the $1920 \mathrm{~s}$. Because influenza A can persistently infect cells and has a marked propensity to mutate it is an optimal candidate among other RNA viruses for delayed nervous system infection as a possible cause of ALS/PD.
\end{abstract}

RÉSUMÉ: Ressemblances de la SLA/MP de Guam et du parkinsonisme/SLA post-encéphalitique: une cause virale possible La sclérose latérale amyotrophique avec parkinsonisme et démence de Guam (SLA/MP) a fait l'objet d'études intensives depuis sa découverte en 1947, à cause de son incidence extraordinairement élevéc dans un petit groupe ethnique (Chamorros) où l'on a soupçonné des déficiences diététiques et certaines coutumes comme causes possibles de la maladie. À date, il a été impossible d'apporter des preuves en ce sens ou de confirmer le rôle de toute autre cause qu'on a coupçonné. À cause d'une grande ressemblance entre la SLA/MP de Guam et du parkinsonisme postencéphalitique (encéphalite léthargique) à début tardif avec SLA, nous suggérons qu'ils ont une cause commune. Le parkinsonisme et la SLA dans les deux maladies sont cliniquement très semblables et les études neuropathologiques ont montré une distribution trés similaire des amas neurofibrillaires dans les neurones. Certaines différences cliniques, telles les manifestations oculaires dans les cas post-encéphalitiques et la démence dans la SLA/MP de Guam, peuvent être expliquées par des différences dans la sévérité de l'infection et l'intervalle entre l'encéphalite et l'appartion des séquelles. Bien qu'on n'en ait aucune preuve, le virus de l'influenza A (la souche HswilNI) a longtempts été soupçonne comme étant la cause de l'encéphalite léthargique à cause de pandémies simultanées de ces deux maladies dans les années 1920. Parce que le virus de l'influenza A peut causer une infection cellulaire persistante et qu'il a une tendance marquée à la mutation, il est un candidat de choix comme cause possible de la SLA/MP parmi les virus à ARN causant une infection retardée du système nerveux.

Can. J. Neurol. Sci. 1990: 17: 427-433

The etiology of Parkinson's disease (paralysis agitans) and amyotrophic lateral sclerosis (ALS) is unknown despite efforts to identify toxins, genetic factors, metabolic disorders and viruses among the possible causes. In the present account evidence is offered in support of two types of parkinsonism and ALS encephalitis lethargica and its sequelae (post-encephalitic parkinsonism/ALS) and Guamanian ALS/parkinsonism-dementia (ALS/PD) - having a common and possibly viral cause. Both diseases have declined in incidence and because they are now rare they were assessed with the aid of numerous past clinical and pathological reports. Whereas encephalitis lethargica has been considered a viral disease which occasionally reaches cpidemic proportions and then subsides, the subsidence of Guamanian ALS/PD, which affects essentially one particular ethnic group (Chamorros) on Guam, Rota and Tinian Islands has been attributed to improvements in the general health and dietary care 
of the affected population following World War II. ${ }^{1-5}$ Some have suggested that calcium deficiency caused the deposition of toxic and essential minerals in neurons while others have proposed neuronal death following exposure to the poisonous cycad seed (Cycas circinalis) as part of dietary or medicinal use.6-9 However, it is uncertain that avoidance of these possible causes has been responsible for the decreased incidence of ALS/PD and there remains the question, therefore, of whether the Guamanian disease was following a natural rather than therapeutic decline.

Attempts to identify virus as the cause of Guamanian ALS/PD have been unrewarding. Gibbs and Gajdusek ${ }^{10}$ in a review of their efforts to transmit ALS/PD to other species commented that no direct or convincing evidence in support of infective cause was obtained although, they added, continued application of newer techniques in search of latent but persistent viruses might disclose a virus. Duvoisin and Yahr" ${ }^{11}$ argued that the rare association of a progressive parkinsonian syndrome with any known type of viral infection "other than encephalitis lethargica has not been shown to be more than coincidental". This view expresses the widely held conviction that encephalitis lethargica is a viral disease although, like ALS/PD, no virus has been identified.

\section{Evidence Linking ALS/PD with Viral INFECTION}

Clinically, in the majority of classical and Guamanian ALS cases the disease begins focally, as in a hand or the tongue, from which site it appears to spread from one neuron to the next over a progressively widening area. In its progression it resembles the known "slow" virus infections of the nervous system such as subacute sclerosing leukoencephalopathy or Creutzfeldt-Jakob disease although the neuronal involvement in ALS is much more selective. In appearance, therefore, the features of ALS are compatible with a virus infection. Various conventional viruses have been considered as possible causes of classical ALS and Guamanian ALS/PD. Poliovirus, especially, has been investigated but searches employing, most recently, a nucleic acid hybridization assay have been negative in both disorders. ${ }^{12.13}$ In classical ALS there have been, from time to time, reports of virus isolation (unconfirmed) or virus-like particles in neurons and skeletal muscle 14.15 .16 but in neither the classical disease nor ALS/PD has there been evidence of virus in in vitro explant cultures of nervous tissue. ${ }^{17.18}$ Inoculation of nervous or other tissue from affected subjects into subhuman primates also has failed to demonstrate transmissibility of the disease. ${ }^{10.17}$

Maurizi ${ }^{19}$ also believed that the high incidence of ALS/PD on Guam may have the outcome of an attack by a neurovirulent (influenza) virus and suggested that the Chamorro population was vulnerable due to their relative genetic isolation. O'Brien et $\mathrm{al}^{20}$ have described how a lack of genetic variability in some animal species has resulted in genetic monomorphism of a major histocompatibility complex and a marked susceptibility to certain viral infections.

\section{Why Attempts to Identify Virus are Unsuccessful}

Although virus infection has often been considered as a cause of ALS there are many difficulties that can prevent its discovery. Viruses can have complex growth requirements and are difficult to culture. The identification of influenza virus, for example, depended on the development of the chick embryo isolation technique. Host susceptibility, also, is often limited and transmission to suitable experimental animals may not be successful. Sometimes a virus is not present in a conventional form and if defective it can elude identification unless co-cultivated with a complementary virus. Negative serological surveys also may be unreliable because serological studies can identify antibodies only to known antigens and some viruses, such as the influenza viruses, change their envelop antigens. Damage to cells can be the result of an immune response directed at a virusself complex or shared epitopes of specific host antigens making a causal relationship with virus difficult to establish.21

\section{Features of Encephalitis lethargica, Post-Encephalitic Parkinsonism/Als and Guamanian ALS/PD}

Encephalitis lethargica was first described by von Economo in 1917 at the beginning of a pandemic that peaked in 1920 and again in 1924 and then declined with only very occasional reports of cases of encephalitis or post-encephalitic parkinsonism/ALS after 1930.22 Small epidemics of encephalitis lethargi$\mathrm{ca}$, referred to under a variety of names, such as febris comatosa and nona, probably have been recurring throughout the world for centuries but reliable records are not available.' The swine influenza A pandemic also appeared at the same time as von Economo's encephalitis in the second decade of this century and continued for more than a decade thereafter. Because of their coincidence the influenza virus has been thought by a number of investigators to have also been the cause of encephalitis lethargica. ${ }^{23}$

Guamanian ALS/PD was first recognized in 1947 and because of some similarities to post-encephalitic parkinsonism it was thought to be due to encephalitis lethargica. ${ }^{2}$ Subsequently, however, environmental toxins were considered a more likely cause and the quite marked similarities between the two conditions were not further explored. 3.6 .7 .24 .25

\section{Clinical Features}

\section{(i) Encephalitis lethargica and its sequelae.}

The encephalitic stage. Encephalitis lethargica in the 1920s was characterized by von Economo ${ }^{1}$ as a specific acute infectious disease with a short prodromal stage of a few days or occasionally a week that began with an elevated temperature and mild pharyngitis and evolved into a state of "general discomfort, lassitude, seediness, shivering, headache, occasional vertigo and vomiting". This "influenza-like" prodrome was followed by one or other of three major forms of the disease. ${ }^{1}$ The mortality rate was variable but close to $50 \% .22$

The "somnolent-ophthalmoplegic" form of encephalitis lethargica was the most common manifestation of the disease. Following the prodrome the patient became somnolent but could be quickly aroused and would be fully alert and responsive. Arousal was brief and the patient soon dropped back to sleep. Sleepiness would persist for days or in severe cases for weeks or months. In the latter it tended to gradually deepen to a more or less constant sleep from which arousal was difficult but still possible except when the patient became comatose. Often, during the first days of the illness various cranial nerve palsies appeared, especial y ptosis and extraocular muscle weakness. Von Economo attributed the combination of sleepiness and ocular palsies to inflammatory lesions in the upper midbrain. Other 
less common features of this form of the disease were parkinsonian rigidity, chorea and seizures.

A "hyperkinetic" form of encephalitis lethargica had, as its main feature, severe motor unrest in place of the sleepiness that characterized the somnolent-ophthalmoplegic form. Following the prodrome of influenza-like symptoms the patient abruptly experienced severe headache, generalized pains, vomiting, extreme agitation, various (especially respiratory) tics, inverted sleep rhythm, incoherent speech and delusions, lasting for several days or weeks or longer, possibly months. Pupillary disorder, but not extraocular muscle weakness, was common in this form of the encephalitis. Chorea and myoclonic twitching and sometimes seizures accompanied psychomotor excitement. The hyperkinetic state was at times followed by somnolence, either intermittently or continuous, lasting days and as in the somnolentophthalmoplegic form of encephalitis this was often accompanied by ptosis and extraocular muscle weakness.

A "parkinsonian" form of encephalitic lethargica, in which the patient had a rigid parkinsonian appearance, sometimes followed the initial influenza-like symptoms. The patient would appear generally weak and lay with eyes closed but not asleep. There was a marked paucity and slowness of movement and a catatonic state wherein postures were maintained involuntarily for long periods. Sleep inversion accompanied by some psychomotor excitement, delusions, pupillary disturbances and occasionally extraocular muscle weakness also occurred. The disorder would persist for weeks or months with either improvement or death of the patient. This form of encephalitis was common to those who later developed post-encephalitic parkinsonism (see below).

Early onset post-encephalitic parkinsonism In early onset post-encephalitic parkinsonism as described in the 1920 s the interval between encephalitis and onset of parkinsonism seldom exceeded 6 months and young adults, less than 30 years of age, were principally affected. $11,26,27$ The appearance of rigidity was greater in degree than paralysis agitans but muscular tone was actually less (Table 1). Tremor was coarse or often absent and rarely "pill-rolling" in type. Ocular abnormalities included, in various combinations, defective convergence (the only ocular feature along with poor upward gaze, which ordinarily accompanies paralysis agitans), poor pupillary response to accommodation, impaired extraocular movement, ptosis, oculogyric crises and nystagmus. Mental symptoms were also more striking than in paralysis agitans. The patients were lethargic and emotionally unstable and were sometimes delusional. Some patients developed typical ALS in this early period either independently of, or in addition to, parkinsonism. ${ }^{28}$

Late onset post-encephalitic parkinsonism Onset of parkinsonism appeared sometimes within a year or as many as 20 years following encephalitis. ${ }^{26}$ The average age of onset was about 40 years or more. Rigidity more closely resembled paraly. sis agitans than early onset post-encephalitic parkinsonism and tremor was now more prominent and "pill-rolling" in type (Table 1). Mental symptoms were less striking but still present to some degree and consisted mainly of altered sleep rhythm, emotional instability and depression. Dementia was not described. Eye signs, such as oculogyric crises, characteristic of early post-encephalitic parkinsonism, were still common but not as prominent. In general, distinction between paralysis agitans and post-encephalitic parkinsonism became increasingly difficult as the interval between the encephalitis and onset of parkinsonism increased. Moreover, mild encephalitic illnesses yielded parkinsonism that was almost indistinguishable from paralysis agitans and closely resembled Guamanian parkinsonism. ${ }^{26}$ In the late as in the early period following encephalitis some patients developed ALS, either independently or in association with parkinsonism (see below).

Post-encephalitic amyotrophic lateral sclerosis Von Economol mentioned, but did not describe, post-encephalitic cases who had a motor neuron disorder with striking clinical and pathological resemblance to ALS. Post-encephalitic ALS has received remarkably little attention although there are at least 25 case reports with upper and lower motor neuron signs, some with bulbar involvement, that were indistinguishable from classical ALS. 28 The average age of the encephalitis was 28 years and the interval to onset of ALS averaged 10 years. Parkinsonism accompanied ALS in two-thirds of the cases and usually appeared before or at the same time as ALS. Life expectancy was less than 4 years.

\section{(ii) Guamanian ALS/PD}

In Guamanian ALS/PD the age of onset in the early postWorld War II years was 40 or more years of age. The appearance of parkinsonian rigidity was the same as paralysis agitans and muscular tone had similar lead pipe or cogwheel resistance but tremor was only mild to moderate and not typically "pillrolling" in type. ${ }^{29}$ The ocular features consisted of impaired convergence and upward gaze, the same as in paralysis agitans. Mental symptoms included depression, emotional instability, delusions, behavioural disorder and altered sleep rhythm (similar to post-

Table 1: Comparison of Different Types of Parkinsonism

\begin{tabular}{llllll}
\hline Type & Appearance & Tremor & Tone & Ocular Signs & Mental State \\
\hline Idiopathic: & $\begin{array}{l}\text { rigid; } \\
\text { bradykinesis }\end{array}$ & $\begin{array}{l}\text { rhythmic; } \\
\text { pill-rolling }\end{array}$ & $\begin{array}{l}\text { increased; } \\
\text { cogwheel }\end{array}$ & $\begin{array}{l}\text { poor convergence and } \\
\text { upward gaze }\end{array}$ & $\begin{array}{l}\text { depression; slowed thought; } \\
\text { hallucinations in elderly }\end{array}$
\end{tabular}

Post-encephalitic:

$\begin{array}{llll}\text { Early - } & \begin{array}{l}\text { rigid; } \\ \text { bradykinesis }\end{array} & \begin{array}{l}\text { irregular } \\ \text { and coarse }\end{array} & \begin{array}{l}\text { hypotonic; } \\ \text { catatonic } \\ \text { posture }\end{array} \\ \text { Late - } & \begin{array}{l}\text { rigid; } \\ \text { bradykinesis }\end{array} & \begin{array}{l}\text { rhythmic; } \\ \text { fine, pill-rolling }\end{array} & \begin{array}{l}\text { increased; } \\ \text { cogwheel }\end{array}\end{array}$

Guamanian:

rigid; bradykinesis rhythmic; fine, not increased; lead typical pill-rolling pipe or cogwheel oculogyric spasm; poor convergence, accommodation: ophthalmoplegia

oculogyric spasm: weak accommodation, convergence, upward gaze

impaired convergence lethargy; depression: various tics; delusions; sleep and behavioural disturbance depression; respiratory tics; sleep disturbances; emotional instability dementia; depression; sleep and behavioural disturbance 
encephalitic parkinsonism). Dementia consisting of poor memory, reduced comprehension and disorientation in time and place was frequent but not invariable.

Guamanian ALS was indistinguishable from classical ALS apart from minor differences such as a slightly more protracted course, younger age of onset, more frequent pyramidal tract signs initially and the association of mental changes. In all of these aspects it more closely resembled post-encephalitic ALS. It was frequent and occurred both independently and as an accompaniment to parkinsonism and dementia. ${ }^{29}$

\section{Pathological Features}

The pathological changes in encephalitis lethargica and early post-encephalitic parkinsonism/ALS consisted, mainly, of extensive inflammatory perivascular lymphocytic infiltration, but acute inflammatory changes had disappeared in the late onset post-encephalitic parkinsonism cases. Neither were they found in Guamanian ALS/PD.

The pathological changes in late post-encephalitic parkinsonism/ALS and in Guamanian ALS/PD were very similar. The most characteristic changes were extensive loss of neurons, astrocytic gliosis and neurofibrillary tangles in neurons. In both conditions the neurofibrillary tangles were conspicuous and consisted of $10 \mathrm{~nm}$ filaments and corresponded to the regions of neuronal loss and gliosis. $25.30-34$ The distribution of tangleaffected neurons throughout the nervous system in the two conditions was essentially the same (Table 2). This was especially evident when comparison was made with progressive supra- nuclear palsy and Alzheimer's disease where the distribution appears quite different. ${ }^{33}$ Neurofibrillary tangles occur in a variety of other brain disorders but their distribution is seldom detailed sufficiently to allow comparisons. The number of tangleaffected neurons is generally much less striking in other encephalopathies than in the above conditions. ${ }^{35.36}$ Neurofibrillary tangles are not a feature of paralysis agitans nor classical ALS.

In summary, the differences between late post-encephalitic parkinsonism/ALS and Guamanian ALS/PD are mainly the ocular features in the former and dementia in the latter. Guamanian parkinsonism is clinically similar to paralysis agitans apart from minor differences in tremor and the added feature of dementia. Late onset post-encephalitic parkinsonism also closely resembles paralysis agitans except for residual ocular and mental (emotional) disorder from the initial encephalitic illness. As noted by Dimsdale 26 and others, the milder the encephalitis the more closely the parkinsonism features resemblepar alysis agitans. It is probable that the Parkinson's features of both Guamanian ALS/PD and post-encephalitic parkinsonism/ALS have been modified by the widespread nervous system damage. What is surprising, considering the extent of the pathological changes, is that dementia has not been reported in postencephalitic parkinsonism as in the case of ALS/PD. ALS occurring as a sequel of encephalitis lethargica or in Guamanian ALS/PD was clinically identical. The pathological features, notably the distribution of neurofibrillary tangles, in the late post-encephalitic and Guamanian disorders were essentially the same.

Table 2: Neurodegenerative Diseases with Neurofibrillary Tangles: Comparative Distribution of Tangle Affected Neurons $25,30,31,33,34$

\begin{tabular}{|c|c|c|c|c|c|}
\hline Neural Structure & $\begin{array}{c}\text { Guam } \\
\text { ALS }\end{array}$ & $\begin{array}{l}\text { ALS/PD* } \\
\text { PD }\end{array}$ & $\begin{array}{c}\text { Post-Enceph } \\
\text { ALS/Park. }\end{array}$ & $\begin{array}{c}\text { Progressive } \\
\text { Supranuc. Palsy }\end{array}$ & $\begin{array}{c}\text { Alzheimer's } \\
\text { Disease }\end{array}$ \\
\hline \multicolumn{6}{|l|}{$\begin{array}{l}\text { cerebral cortex } \\
\text { general }\end{array}$} \\
\hline frontotemporal & + & + & + & & \\
\hline $\begin{array}{l}\text { frontotemp-parietal } \\
\text { cingulate gyrus }\end{array}$ & & & & & $\begin{array}{l}+++ \\
++\end{array}$ \\
\hline upper motor neurons & +++ & + & ++ & & \\
\hline hippocampus & $+t$ & +++ & ++ & & +++ \\
\hline nucleus basalis & ++ & +++ & + & & + \\
\hline corpus striatum & & & + & & + \\
\hline globus pallidus & + & + & ++ & +++ & \\
\hline thalamus & + & + & + & & + \\
\hline hypothalamus & ++ & +++ & + & & + \\
\hline subthalamic nucleus & + & + & + & +++ & \\
\hline amygdala & + & ++ & & & +++ \\
\hline substantia nigra & ++ & +++ & +++ & +++ & + \\
\hline red nucleus & & & & +++ & \\
\hline \multicolumn{6}{|l|}{ midbrain } \\
\hline superior colliculi & & & & +++ & \\
\hline N. Edinger-Westphal & & & & + & \\
\hline midline structures & ++ & +++ & ++ & & \\
\hline periaqueductal grey & ++ & +++ & + & +++ & \\
\hline reticular formation & + & + & ++ & & \\
\hline locus ceruleus & + & ++ & +++ & ++ & + \\
\hline \multicolumn{6}{|l|}{ tegmentum of pons } \\
\hline inf. olivary complex & & & & ++ & \\
\hline dentate nucleus & & & & +++ & \\
\hline vagal nuclei & + & ++ & + & & + \\
\hline lower motor neurons & +++ & + & +++ & & \\
\hline
\end{tabular}

$*+,++,+++$ - mild, moderate, severe involvement 


\section{A QUESTION OF ENCEPHalitis LeThaRgica on GUAM}

Despite the impressive clinical and pathological similarities between Guamanian ALS/PD and late post-encephalitic parkinsonism/ALS it is difficult to accept the features of ALS/PD as post-encephalitic without a history of encephalitis. Guam in the years before World War II has been viewed as "a fairly isolated island of approximately 25,000 natives and a few military personnel". ${ }^{37}$ Hammon et al ${ }^{38}$ in a study of an epidemic of Japanese B encephalitis (JBE) on Guam in 1947 reported that prior to 1947 there was no evidence that "encephalitis or even an endemic situation resembling JBE (had) ever occurred on Guam". Island people are exposed to illnesses carried on ships from other parts of the world and the people of the Guamanian village of Umatac, which had the highest incidence of ALS/PD, provided ships with water and other supplies as part of their livelihood. ${ }^{5}$ As noted by Ravenholt and Foege ${ }^{23}$ swine influenza and encephalitis lethargica were epidemic on other Pacific islands such as Western Samoa from 1918 to 1922. Even an intensive quarantine as in the case of American Samoa, only $70 \mathrm{~km}$ distant from Western Samoa, merely delayed the influenza epidemic until 1926. While it is difficult to imagine any illnesses such as this bypassed Guam, especially Umatac, either in the 1920s or during World War II when the island was under military occupation there appears to be no historical evidence of a major epidemic of encephalitis on Guam prior to 1947. Nevertheless, it is known that for more than a century prior to 1945 the people of Guam were neglected, severely impoverished and vulnerable to disease. ${ }^{5}$ It is significant that neurofibrillary tangles in neurons, as occur in the ALS/PD cases, were also found in the clinically normal Chamorro nervous system. This finding has provided a strong argument for those who favor Guamanian ALS/PD being due to environmental toxins especially when the disease was found to be non-transmissible to a varicty of animal species. ${ }^{10}$ If ALS/PD is due to infection it is apparent that the infecting agent must not be readily transmissible and perhaps unique in the manner of its infectivity. An infectious agent with such potential might be the influenza virus, especially influenza $A$, because of its properties of persistent infection and mutation and suspected association with the sequelae of encephalitis lethargica. Moreover, as Maurizi ${ }^{19}$ has proposed, because of their relative isolation the Chamorros might have been genetically more susceptible to the development of such sequelae.

\section{Possible Latent Viral Infection in Guamanian ALS/PD}

\section{The Influenza Virus and Encephalitis Lethargica}

Although much debated, encephalitis lethargica occurring at the time of the influenza pandemic between 1917 and 1930 is believed by a number of workers to have been caused by the swine (HswilN l) influenza virus. ${ }^{23.39-45}$ Over 50,000 cases of encephalitis lethargica were recorded, worldwide, between 1919 and 1927.22 During the same period there were millions of deaths from influenza. The influenza virus characteristically produced an upper respiratory infection but encephalitis and other neurological conditions may accompany an acute infection. 46 According to Ravenholt and Foege ${ }^{23}$ there was a close correlation in the peak incidences of influenza and encephalitis lethargica during the pandemics. There have been only scattered reports of cases of encephalitis lethargica and post-encephalitic parkinsonism/ALS after 1930 but there has been no abatement in the influenza pandemics. ${ }^{47-50}$ For example, there was the Asian influenza $A(H 2 N 2)$ pandemic in 1957 and Hong Kong influenza A (H3N2) in 1968, but the strains of virus have been much less virulent than the earlier HswilNI strain. The influen$\mathrm{za} A$ virus is an RNA virus with extraordinary latent infective and mutational properties that has been the reason for frequent major epidemics and the differences in virulence of each new strain. 51 The virus in any of its known forms appears capable of mutation to lethal neurotropic variants although this seems especially marked with the HswilNI strain. 52

\section{Possible Role of Influenza or Similar Virus and Guamanian ALS/PD}

During the acute phase of infection the influenza or similar virus may be carried in the circulation and can gain access to the nervous system by two routes: (i) direct entry to produce encephalitis and thereby direct invasion of structures such as the substantia nigra and (ii) indirect entry via peripheral nerve and retrograde axoplasmic transport to the cell body in the central nervous system. The latter route is especially likely to explain lower motor neuron degeneration as the virus enters from the motor end plate region in skeletal muscle to take residence in the cell body of the lower motor neuron where it remains, indefinitely, as a latent infection. ${ }^{53} \mathrm{~A}$ virus within a neuron at any site within the nervous system may be either a whole or a defective virus. The sequestered intracellular environment of the persistently infected cells favor rapid and continuous mutation of virus and defective particles. ${ }^{54}$ After a latent interval these may mutate to a form that may suppress macromolecular synthesis and degeneration of the neuron. The mutant gene and/or its product may then be transferred to adjacent neurons producing a continuous loss of interconnected neurons. While there are other RNA viruses with similar potential, such as the vesicular stomatitis virus and rotaviruses, the influenza $A$ virus is a prime candidate because of its historical relationship with encephalitis lethargica. 51.55

In conclusion, the clinical and pathological similarities between late post-encephalitic parkinsonism/ALS and Guamanian ALS/PD, suggest a common etiology. Influenza $A$ has been suspected as the cause of encephalitis lethargica and because of its tendency to persistent (latent) infection and mutation, sometimes to a neurotropic variant, it may be the cause of post-encephalitic ALS/parkinsonism. Although there has been no history of encephalitis on record as having preceded Guamanian ALS/PD it also might have been caused by influenza $A$ or virus with similar properties.

\section{REFERENCES}

1. von Economo C. Encephalitis lethargica: its sequelae and treatment. London: Oxford University Press, 1931.

2. Mulder DW, Kurland LT, Iriarte LLG. Neurologic discases on the Island of Guam. U.S. Armed Forces Med J 1954; 5: 1724-1739.

3. Hirano A, Kurland LT, Krooth RS, et al. Parkinsonism-dementia complex, an endemic disease on the Island of Guam. I. Clinical features. Brain 1961; 84: 642-661.

4. Armon C, Kurland LT. Classic and Western Pacific amyotrophic lateral sclerosis: epidemiologic comparisons. In: Hudson AJ, ed. Amyotrophic lateral sclerosis: concepts in pathogenesis and etiology. Toronto: University of Toronto Press, 1990; 144-165. 
5. Steele JC, Guzman TQ, Driver MG, et al. Nutritional factors in amyotrophic lateral sclerosis on Guam: observations from Umatac. In: Hudson AJ, ed. Amyotrophic lateral sclerosis: concepts in pathogenesis and etiology. Toronto: University of Toronto Press, 1990; 193-223.

6. Garruto RM, Swyt C, Yanagihara R, et al. Intraneuronal co-localization of silicon with calcium and aluminum in amyotrophic lateral sclerosis and parkinsonism with dementia of Guam. New Engl J Med 1986; 315: 711-712.

7. Spencer PS, Nunn PB, Hugon J, et al. Guam amyotrophic lateral sclerosis-parkinsonism-dementia linked to a plant excitant neurotoxin. Science 1987; 237: 517-522.

8. Gajdusek DC. Cycad toxicity not the cause of high-incidence amyotrophic lateral sclerosis/parkinsonism-dementia on Guam. Kii Peninsula of Japan, or in West New Guinea. In: Hudson AJ, ed. Amyotrophic lateral sclerosis: concepts in pathogenesis and etiology, Toronto: University of Toronto Press, 1990; 317-325.

9. Grima EA, Bergeron C, Crapper McLachlan DR. Evaluation of environmental factors in the etiopathogenesis of the amyotrophic lateral sclerosis/parkinsonism-dementia complex of Guam. In: Hudson AJ, ed. Amyotrophic lateral sclerosis: concepts in pathogenesis and etiology. Toronto: University of Toronto Press, 1990; 224-262.

10. Gibbs Jr CJ, Gajdusek DC. Amyotrophic lateral sclerosis, Parkinson's disease, and the amyotrophic lateral sclerosisparkinsonism-dementia complex on Guam: a review and summary of attempts to demonstrate infection as the aetiology. J Clin Pathol 1972; 25 (Suppl): 132-140.

11. Duvoisin RC, Yahr MD. Encephalitis and parkinsonism. Arch Neurol 1965; 12: 227-239.

12. Kohne DE, Gibbs CJ, White L, et al. Virus detection by nucleic acid hybridization: examination of normal and ALS tissues for the presence of poliovirus. J Gen Virol 1981; 56: 223-233.

13. Viola MV, Lazarus $M$, Antel $J$, et al. Nucleic acid probes in the study of amyotrophic lateral sclerosis. In: Lewis P. Rowland, ed. Human motor neuron diseases. New York: Raven Press, 1982; 317-329.

14. Pena GE. Viruslike particles in amyotrophic lateral sclerosis. Electron microscopical study of a case. Ann Neurol 1977; 1: 290-297.

15. Oshiro LS, Cremer NE, Norris FH, et al. Viruslike particles in muscle from a patient with amyotrophic lateral sclerosis. Neurology 1976; 26: 57-60.

16. Kascsak RJ, Carp RI, Vilcek JT, et al. Virological studies in amyotrophic lateral sclerosis. Muscle \& Nerve 1982; 5: 93-101.

17. Gibbs CJ, Gajdusek DC. An update on long-term in vivo and in vitro studies designed to identify a virus as the cause of amyotrophic lateral sclerosis, parkinsonism dementia, and Parkinson's disease. In: Rowland LP, ed. Human motor neuron diseases. New York: Raven Press, 1982; 343-353.

18. Weiner LP, Stohlman SA, Davis RL. Attempts to demonstrate virus in amyotrophic lateral sclerosis. Neurology 1980; 30: 13191322.

19. Maurizi CP. Was a neurovirulent influenza virus the cause of amyotrophic lateral sclerosis and parkinsonism-dementia on Guam? Medical Hypotheses 1987; 23: 325-326.

20. O'Brien SJ, Roelke ME, Marker L, et al. Genetic basis for species vulnerability in the cheetah. Science 1985; 227: 1428-1434.

21. Laing P, Knight JG, Hill JM, et al. Influenza viruses induce autoantibodies to a brain-specific 37-KDa protein in rabbit. Proc Natl Acad Sci 1989; 86: 1998-2002.

22. Matheson Commission. Epidemic encephalitis; etiology, epidemiology, treatment. New York: Columbia University Press, 1929; 179-399.

23. Ravenholt RT, Foege WH. 1918 influenza, encephalitis lethargica, parkinsonism. Lancet 1982; ii: 860-864.

24. Arnold A, Edgren DC, Palladino VS. Amyotrophic lateral sclerosis. Fifty cases observed on Guam. J Nerv Ment Dis 1953; 117: 135139.

25. Hirano A, Malamud N, Kurland LT. Parkinsonism-dementia complex, endemic disease on the Island of Guam. II. Pathological features. Brain 1961; 84: 662-679.
26. Dimsdale H. Changes in the parkinsonian syndrome in the twentieth century. Quart J Med 1946; 15: 155-170.

27. Brain WR. Diseases of the Nervous System. London: Oxford University Press, 4th edition, 1951.

28. Hudson AJ. Amyotrophic lateral sclerosis and its association with dementia, parkinsonism and other neurological disorders. A review. Brain 1981; 104: 217-247.

29. Elizan TS, Hirano A, Abrams BM, et al. Amyotrophic lateral sclerosis and parkinsonism-dementia complex of Guam. Arch Neurol 1966; 14: 356-368.

30. von Braunmuhl AV. Encephalitis epidemica und synaresislehre. Grundsatzliches zure anatomie und pathogenese des postencephalitischen parkinsonismus. Archiv Psychiatrie 1949; 181: 543-576.

31. Greenfield JG, Matthews WB. Post-encephalitic parkinsonism with amyotrophy. J Neurol Neurosurg Psychiatry 1954; 17: 50-56.

32. Greenfield JG, Bosanquet FD. The brain-stem lesions in parkinsonism. J Neurol Neurosurg Psychiatry 1953; 16: 213-226.

33. Hirano A, Zimmerman HM. Alzheimer's neurofibrillary changes: a topographic study. Arch Neurol 1962; 7: 227-242.

34. McMenemey WH, Barnard RO, Jellinek EH. Spinal amyotrophy. A late sequel of epidemic encephalitis (von Economo). Revue Roumaine du Neurologie 1967; 4: 251-259.

35. Gajdusek DC. Hypothesis: interference with axonal transport of neurofilament as a common pathogenetic mechanism in certain diseases of the central nervous system. New Engl J Med 1985; 312: 714-719.

36. Corsellis JAN. Sub-acute sclerosing leuco-encephalitis: a clinical and pathological report of two cases. J. Ment Sci 1951; 97: 570583.

37. Edgren DC, Palladino VS, Arnold A. Japanese B and mumps encephalitis. A clinicopathological report of simultaneous outbreaks on the Island of Guam. Am J Trop Med Hyg 1958; 7 : 471-480.

38. Hammon WMcD, Tigertt WD, Sather GE, et al. Epidemiologic studies of concurrent "virgin" epidemics of Japanese B encephalitis and of mumps on Guam, 1947-1948, with subsequent observations including dengue, through 1957. Am J Trop Med Hyg 1958; 7: 441-468.

39. Crookshank FG. Epidemic encephalomyelitis and influenza. Lancet 1919 ; i: $79-80$

40. Poskanzer DC, Schab RS. Cohort analysis of Parkinson's syndrome: evidence for a single aetiology related to subclinical infection about 1920. J Chron Dis 1963; 16: 961-973.

41. Gamboa ET, Wolf A, Yahr MD, et al. Influenza virus antigen in postencephalitic parkinsonism brain: detection by immunofluorescence. Arch Neurol 1974; 31: 228-232.

42. Mattock C, Marmot M, Stern G. Could Parkinson's disease follow intra-uterine influenza?: a speculative hypothesis. J Neurol Neurosurg Psychiatry 1988; 51: 753-756.

43. Ebmeier KP, Mutch WJ, Calder SA, et al. Does idopathic parkinsonism in Aberdeen follow intrauterine influenza? J Neurol Neurosurg Psychiatry 1989; 52: 911-913.

44. Elizan TS, Casals J. No viral antigens detected in brain tissue from a case of acute encephalitis lethargica and another case of postencephalitic parkinsonism. J Neurol Neurosurg Psychiatry 1989; 52: 800-801.

45. Singer C, Weiner WJ. Could Parkinson's disease follow intra-uterine influenza? A speculative hypothesis. J Neurol Neurosurg Psychiatry 1989; 52: 931 .

46. Stuart-Harris CH, Schild GC, Oxford JS. Influenza. The viruses and the diseases. London: Edward Arnold Ltd, 2nd edition, 1985.

47. Espir MLE, Spalding JMK. Three recent cases of encephalitis lethargica. Br Med J 1956; 1: 1141-1144.

48. Clough CG, Plaitakis A, Yahr MD. Oculogyric crises and parkinsonism: a case of recent onset. Arch Neurol 1983; 40: 3637.

49. Howard RS, Lees AJ. Encephalitis lethargica: a report of four recent cases. Brain 1987; 110: 19-33.

50. Johnson J, Lucey PA. Encephalitis lethargica, a contemporary cause of catatonic stupor: a report of 2 cases. Br J Psychiatry $1987 ; 151: 550-552$. 
51. Hope-Simpson RE, Golubev DB. A new concept of the epidemic process of influenza A virus. Epidem Inf 1987; 99: 5-54.

52. Stuart-Harris $\mathrm{CH}$. A neurotropic strain of human influenza virus. Lancet 1939; i: 497-499.

53. Armstrong CL, Miranda AF, Hsu KC, et al. Susceptibility of human skeletal muscle culture to influenza virus infection. I. Cytopathology and immunofluorescence. J Neurol Sci. 1978; 35 : 43-57.
54. Holland JJ, Grabau EA, Jones CL, et al. Evolution of multiple genome mutations during long term persistent infection by vesicular stomatitis virus. Cell 1979; 16: 495-504.

55. Editorial. Puzzling diversity of rotaviruses. Lancet 1990; i: 573 574. 